\title{
Liberating Science of Health Education for Masses
}

Prof. Dr. Mathura P. Shrestha*

Like any learning principle, health education is to liberate people, especially the deprived and disempowered, with an objective of empowering them to informed decisions and actions with holistic understanding of the subject or the problem or problem concerned, after owning them as integral parts of their own. By 'owning the subject or problems(s)', I mean that the people understand and resolve with confidence that they (subjects or problems) are their own, that they have to solve by themselves and that they can solve.

This is easily said and done. We have to analyze and understand the historical, political, psychological and cultural perspectives in addition to their physical environment. According to Ron Miller, Holistic Education is a philosophy of education based on the premise that each person finds identity, meaning and purpose in life through connections to the community, to the natural world, and to humanitarian values such as compassion and peace. Holistic education aims to call forth from people an intrinsic reverence for life and a passionate love of learning.

In Nepal where so called Guru-chela tradition is entrenched so deeply and so ubiquitously, prescriptive mentality among the givers and receivers of health or any education is a usual norm. With this norm, according Paulo Freire, "education becomes an act of disposing.... This is the 'banking' concept of education" projecting an absolute ignorance on to others, a characteristic of the ideology of oppression (or enslavement), negates education and knowledge as process of inquiry.... This solution (raison d'être of liberation education ... towards solution of problems ... with reconciliation of the teacher student contradiction) is not, nor can it be found in banking concept. On the contrary, banking education maintains and even stimulates the contradiction through the following practices, which mirror oppressive society as a whole:

1. The teacher teaches and students are taught.

2. The teacher knows everything and the students know nothing.

3. The teacher thinks and the students are thought about.

4. The teacher talks and the students listenmeekly.

5. The teacher disciplines and the students are disciplined.

6. The teacher chooses and enforces his choice and the students comply.

7. The teacher acts and the students have the illusion of acting through the action of the teacher.

8. The teacher chooses the program content, and the students (who were not consulted) adapt to it.

9. The teacher confuses the authority of knowledge with his own professional authority, which he sets in opposition to the freedom of the students.

10. The teacher is the subject of the learning process, which the pupils are mere objects. ${ }^{1}$

Earlier record of departure from authoritarian 'Guru-chela' mode of learning occurred in ancient China with theories and practices propounded by Confucius or Qui Zhongni (551-479 BC), philosopher and educationist, followed by many education-philosophers. It started with three streams of theories, like:

* Keynote address by Former Health Minister in the 13th Annual Meeting of HEAN, Kathmandu, September 8, 2011

1. Paulo Freire (Translated by Myra Bergman Ramos). Pedagogy of the Oppressed. Penguin Books, 1985:54-47.

(C) 2018 HEAN 
a) Theory of 'no distinction' in education, stressing equality among learners, irrespective of any physical, social, cultural, economic and geographic attributes and between teachers and students.

b) 'Teaching should be given to all people without discrimination towards ranks or social status. Confucius said, "The 'son of Heaven' (emperor/king) has lost control of education and it became available to ordinary people in remote areas".

c) Theory of holism meaning learning should comprise of all aspect around human life, especially the spheres of history, literature and music, philosophy, politics, economics, culture and education.

Principle characteristics of ancient Chinese learning traditions emphasised among the learners: 1. Follow truth from facts and respecting ethics (this way, education was made independent of religion), 2. Self control and self cultivation or 'demand much from oneself and little from others', 3 Benevolence, love, filial piety and fraternal duty, or 'Love others', 4. Of being trustworthy and courteous, 5. Of being devoted to the service of the nation, 6. Working for the interest of the public: 7 . Controlling desire for personal gain with the sense of righteousness: 8. Hardworking, thrifty and uncorrupted: 9. Down-to-earth and understanding: 10. Striving unremittingly for progress. $^{2}$

Siddhartha Buddha (6 $6^{\mathrm{TH}}$ century BC) experimented on himself to discover the illusion of them traditional ways of thinking, learning and doing. With his enlightenment he found that 'human and only a human can become Buddha. Every human has within himself the potentiality of becoming a Buddha, if he so wills and endeavors ..., Human's position is ... supreme. Human is his own master, and there is no higher being or power in judgment over his destiny. ${ }^{3}$

I brought Buddha's example here for two reasons: Firstly, he after all sufferings in pursuit of enlightenment he experimented on self-learning and succeeded. Secondly, he rather than be engaged in pedantic sermons, involved the listeners in interactive dialogue. Rather than giving answer or solutions he presented the conditions or situations whereby the listener could conceive the answers or solutions actively, clearly and thoroughly. That way, he heralded the effective, participatory and interactive learning practice or method.

Classical education system creates more problems than it solves. Evan Illich, the great critic, philosopher was so disillusioned with current education system that, in his famous article on Deschooling Society, 1971, he suggested, "The current search for new educational funnels must be reversed into the search for their institutional inverse: educational webs which heighten the opportunity for each one to transform each moment of his living into one of learning, sharing and caring." $\mathrm{He}$ also wrote in his another articles, Tools for Conviviality, 1973, "Invert the present deep structure of tools" in order to " give people tools that guarantee their right to work with independent efficiency."

Health right and health status have synergistic relationship with rights to educations for all. To me, education is a process of continuous and conscientious learning to become liberated from related ignorance or the myths. One is to be able to take informed, free responsible decisions in transparent and accountable manner. Delearning is often necessary of many values and concepts imposed on us by so called modern or classical education systems. It is a right and responsibility of all humans.

2. Guo Qijia. A History of Chinese Educational Thought. Beijing: Foreign Language Press, 2006.

3. Walpola Rahula. What the Buddha Taught. Dehiwala, Sri Lanka: Buddhist Cultural Centre, 1996. 
We must understand that education is not only learning for academic purposes or for academic excellence, or for any ornamental purpose. By learning to be educated a human or all humans must qualify following five elements:

- $\mathrm{He} / \mathrm{she}$ must comprehend the subject matter (in this case, public health) holistically. Comprehension is not merely learning, but understanding of a subject as fully as possible or in its totality-both macro and microscopically.

- $\mathrm{He} /$ she should acquire credible competency with ongoing progression on the subject matters.

- He/she must always be able to examine the subject matter critically. Dogmatism an static knowing and doing antagonize true learning as well as learning spirit. With ability to critical analysis one is also become capable to rational synthesis.

- $\mathrm{He} / \mathrm{she}$ always be creative or committed to creativity. Creativity is not only to be able to reproduce the learned knowledge or skills but also to develop new knowledge, new ways of thinking and doing, new technology, new systems and new culture. It is also for discarding untrue hypes and myths that came with existing knowledge systems. For this, one has to have a knack to be engaged in continuous, ongoing research, innovation and capacity development.

- Lastly, he/she must develop sufficient confidence to move forward.

Education should not be and cannot be imprisoned in any ways or by any means. The dilemma about the question of so called intellectual proprietary rights (IPR) and patency rights (PR) should be taken under the same general truth and need be denounced. In the past many, ruling or exploiting class, tried to imprison the knowledge by one or other way. They did not succeed. Nor anyone succeed, even with new rhetoric to enslave knowledge. Knowledge is the most precious among the common human-goods or products of civilization. True scientists or artists never hanker to enforce IPR or PR. ${ }^{4}$

Dominating class, particularly the colonialists, imperialists, super power hegemony and exploiting, ruling class, always try to domesticate the people with prescriptive education methodology, systems, institutions and norms. They even dissociate people from their natural environment, roots, languages and culture. Any domination that threats freedom to seek truth from facts, either to teachers or learners and their learning environment must be opposed. Worst kind of enslavement that bars people to learn properly and holistically is the one that suppresses mental and cultural domain. Thus learning process, among other things, is a continued struggle to decolonize mind of self, people. The great African writer, thinker and philosopher, Ngûgi wa Thing'o wrote:

The real aim of colonialism was to control the people's wealth: what they produced, how they produced it and how it was distributed to control in other words, the entire realm of the language of real life. Colonialism imposed its control of the social production of wealth. But the most important area of domination was the mental universe of the colonized, the control, through culture, of how people perceived themselves and their relationship to the world. Economic and political control can never be complete or effective without mental control. To control a people's culture is to control their tools of self-determination in relationship to others. ${ }^{5}$

4. Mathura P Shrestha. Public Health Concept: Theoretical and Philosophical 5. Ngugi wa Thing'0. Decolonizing the Mind-The politics of language in African Literature. London: James Curry, or Harare: Zimbabwe Publishing House, 1986, Reprinted 1987: 28. aFoundations. Second Nepal Public Health Foundation Lecture Series, September, 2011. 
To conclude, we together should construct our ability to shift from prescriptive to 'development with together' paradigm. Even educated, experts and professionals are unfortunately susceptible to prescriptive mentality and dictating habits with high sounding discourses. People are kept disabled by our pedantic prescriptions. 'Developing with together' is to develop our concept, purpose, strategy and evaluation systems together with all stakeholders, most importantly, the people, to whom all products of our knowledge and labor is destined. We have to invest our thinking on Lao-Tsu's poem, quoted bellow, to learn from people, from things or conditions and nature to tune up our knowledge and abilities to go ahead. We have got to empower people to take initiatives and evaluate public health services and projects. That is what public participation in real, practical sense.
Go

to the People:

Live among them:

Love them:

Learn from them:

Start from where they are:

Work with them:

Build on what they have.

But of the best leaders,

When the task is accomplished,

The work completed,

The people all remark:

"We have done it ourselves"

\section{Lao Tsu}

